\title{
Multimodal meningsskaping i NRK-produksjonen Sangfoni
}

\section{Multimodal meaning-making in the NRK production Sangfoni}

Tidsskriftet Sakprosa

Bind 13, Nummer 1

(C) 2021

10.5617/sakprosa.8126 


\section{Sammendrag}

I denne artikkelen analyseres musikkvideoen Tusen plommer fra barneprogrammet Sangfoni. Serien består av 22 episoder som hver tar for seg en klassisk barnesang med multimodale uttrykksformer. Det filmatiske uttrykket kan forstås som sakprosa for barn, som tar sikte på å revitalisere tradisjonelle barnesanger, samtidig som dette kan gi en barnetilpasset innføring i musikkteori. Musikkvideoen blir analysert i en sosialsemiotisk ramme med utgangspunkt i meningspotensialet som ligger i modalitetene sangtekst, musikk og filmbilder. Transkripsjon av multimodale uttrykk blir også drøftet i artikkelen. Spørsmålet som blir besvart i analysen er: Hvilke multimodale meningspotensial kommuniserer musikkvideoen Tusen plommer? Analysen viser at musikkvideoen like mye er en opplæringsvideo i å forstå en 7/8-dels takt som å lære å synge sangen Tusen plommer. Videre viser artikkelen at Sangfoni kan være et godt supplement i musikkundervisningen i grunnskolen, særlig siden det ikke er produsert trykte lærebøker i musikkfaget etter den nye læreplanen, og at digitale ressurser vil egne seg godt for å oppnå ulike kompetansemål.

\section{Abstract}

This article reports on an analysis of the music video A Thousand Plums (Tusen plommer), from the Norwegian children's TV series Sangfoni. Sangfoni consists of 22 episodes which all feature a classical song for children, accompanied by several multimodal resources. The cinematic expression can be understood as a type of factual prose for children, which sets out to revitalize traditional children's songs, and to provide an introduction to music theory aimed at children. The music video is analyzed from a social semiotic perspective, on the basis of the meaning potential which can be found in the lyrics, music and images. The transcription of multimodal resources is also discussed in the article. The article addresses the following research question: Which multimodal meaning-making expressions are conveyed in the video? 
The analysis reveals that the music video is instructional in that it helps both to understand the $7 / 8$ beat, and to learn how to sing the song $A$ Thousand Plums. Furthermore, it shows that Sangfoni may be an asset in music education at the primary school level. The article emphasizes the fact that no textbooks for music education, building on the latest curriculum, have been published yet, and that digital resources can be fruitful to reach the learning goals established in the curriculum.

Nøkkelord: multimodalitet; musikk; film; Barne-tv; transkripsjon; sosialsemiotikk

Keywords: multimodality; music; film; children's television; transcription; social semiotics

\section{Om forfatteren:}

Jan Øyvind Moskvil, f. 1977, er lektor ved Ringshaug skole i Tønsberg. Han har bakgrunn som allmennlærer og utøvende musiker. De siste ti årene har han arbeidet med multimodalitet, med særlig vekt på hvordan musikk bidrar til meningsskaping. 


\section{Multimodal meningsskaping i NRK-produksjonen Sangfoni}

Helt siden NRK startet opp prøvesendinger med barneprogram i 1958, har kanalen formidlet kunnskapsbasert underholdning til barn og unge i hele Norge. Barne-tv ble sendt for første gang den 16. september i 1960 klokken 18.0o, og lenge var dette et magisk tidspunkt for barn (Hake, 2006, s. 11). Da NRK Super kom i 2007, ble det faste tidsvinduet for Barne-tv gradvis visket ut, og med nye streamingtjenester har det blitt mulig å se barneprogram døgnet rundt.

Høsten 2020 ble det innført nye læreplaner i skolen, men i 2021 er det fortsatt ikke produsert trykte læremidler i henhold til den nye læreplanen i musikkfaget. I min artikkel viser jeg hvordan NRK-produksjonen Sangfoni kan fungere som en ny type ressurs for musikkundervisningen siden den er digital og ikke er knyttet til et fast sendetidspunkt. For å undersøke dette potensialet, tar jeg utgangspunkt i den multimodale meningsskapingen som kan identifiseres i musikkvideoen til barnesangen Tusen plommer ${ }^{1}$. Serien introduseres slik på NRK sine nettsider: «Musikk er gøy, og musikk er sammensatt. I Sangfoni utforsker vi hva musikk består av. Vi oppdager rytmer, finner ut av melodier» (Soldal, 2018). Programmene framstår som både lærerike og underholdende, og kan vekke interesse hos både barn og voksne. Hver sesong består av 11 episoder ${ }^{2}$, og en episode varer i cirka ti minutter. Hvert program tar for seg en klassisk, oftest norsk, barnesang som er musikalsk fornyet av komponisten John Vinge. Det er stort sett barn som har de sceniske rollene i programmene. I 2017 og 2018 ble serien nominert til gullruten, samt til Spellemannsprisen i 2017.

\footnotetext{
${ }^{1}$ Musikkvideoen Tusen plommer er å finne på denne adressen: https://tv.nrksuper.no/serie/sangfoni-musikkvideoerplussplusspluss/msus49001715/sesong-1/episode-6

${ }_{2}^{2}$ Første sesong kom høsten 2016, og den andre vinteren 2017.
} 
Før jeg tok fatt på analysen var barnesangen Tusen plommer ukjent for meg, og det var det rytmiske som umiddelbart vakte min interesse da jeg så musikkvideoen for første gang. Sangteksten til Tusen plommer er skrevet av danske Halfdan Rasmussen, og er oversatt til norsk av Inger Hagerup. Melodien er komponert av danske Mogens J. Nissen, og ifølge Nasjonalbiblioteket er sangen utgitt i Norge 11 ganger i ulike barnesangbøker, de fleste fra 70- og 80-tallet. Den siste utgaven av sangen finner vi i Den store sangboken (2009). Programserien Sangfoni presenterte altså sangen Tusen plommer for nye generasjoner, og det at den på nytt løftes fram harmonerer også sterkt med det filmbildene viser i starten av musikkvideoen. I figur 1 ser vi et brassorkester komme løpende opp av kjelleren som om de har funnet en gammel skatt de børster støvet av, og som begynner å skinne på nytt i en ny rytmedrakt.

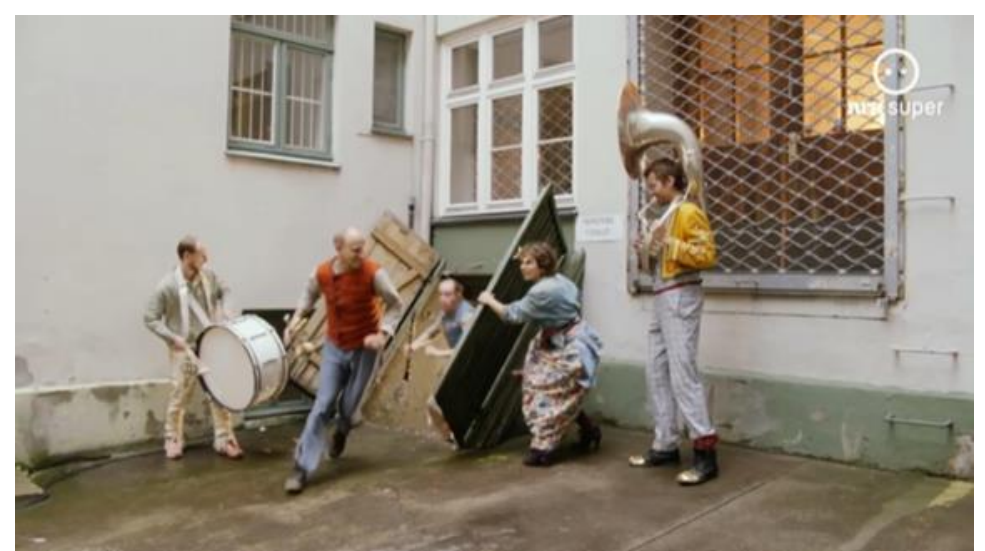

Figur 1: Filmbildene viser brassorkesteret komme løpende opp av kjelleren.

\section{Musikkvideo som sakprosa}

I tidligere multimodale sakprosaanalyser, har man blant annet sett på hvordan samspillet mellom bilder og verbalspråk i lærebøker og aviser skaper mening (Ledin, Höög, Tønnesson, \& Westberg, 2019, s. 19-27), og hvordan auditive ressurser som musikk kan bidra til meningsskaping i en gudstjeneste (Ljones Øierud, 2011). Ledin m.fl. (2019) mener at dagens situasjon krever et vidt sakprosabegrep om begrepet fortsatt skal ha relevans (Ledin et al., 2019, 
s. 28). I dag skaper multimodale tekster helhetlig mening, der skriftspråket tidligere hadde en særstilling ved formidling av sakprosa. Musikkteorien i Sangfoni formidles her multimodalt, ved hjelp av filmteknologi, og ikke bare som stillbilder, noter og verbaltekst i ei bok. I og med at det foreløpig ikke eksisterer trykte læreverk for det nye musikkfaget, er min erfaring som musikklærer at pedagoger benytter seg av blant annet digitale ressurser, som for eksempel Sangfoni. Denne programserien kan legge et grunnlag for opplæring i musikalske byggesteiner som melodi, rytme, puls, klang, tempo, harmoni, toneintervaller, dynamikk og ulike instrumenter. Dette er musikalske elementer som er beskrevet i et eget kompetansemål i den nye læreplanen for musikkfaget etter 2. trinn på grunnskolen (Utdanningsdirektoratet, 2020). Sangfoni blir vist regelmessig på NRK Super, og jeg mener at serien kan egne seg godt som en pedagogisk ressurs i musikkfaget. På denne bakgrunn er det nærliggende å se nærmere på Sangfoni som multimodal sakprosa med et didaktisk siktemål rettet mot barn og andre seere av programmene.

\section{Forskningsspørsmål og beskrivelse av materialet}

I analysen av musikkvideoen Tusen plommer, ønsker jeg å undersøke hvordan samspillet mellom modalitetene musikk, sangtekst og filmbilder arter seg og hvordan de til sammen skaper mening. Forskningsspørsmålet er: Hvilke multimodale meningspotensial kommuniserer musikkvideoen Tusen plommer?

Det rytmiske aspektet er framtredende i Sangfoni, både på et musikalsk nivå, men også på makronivå når man undersøker oppbygningen av de ulike episodene. Hver episode starter med en gjennomgang av dagens sang som synges av barn. Deretter blir melodien spilt på et piano i en stor konsertsal. Dette er filmet ovenfra slik at man ser tangentene det spilles på. Så kommer et innslag som heter «Gjett instrumentet». Her hører man et instrument, og man 
ser tre alternative instrumenter det kan dreie seg om. Neste innslag er en klappelek, og deretter følger «Finn melodien» som neste punkt i programmet. Her viser filmbildene en trapp hvor barn går opp og ned. Trappetrinnene fungerer som pianotangenter som lyser og lager lyd når de blir tråkket på. Barna forsøker her å trampe dagens melodi. Så kommer innslaget «Hør rytmen». Filmbildene viser en mann som dunker rytmen til dagens sang med stokken sin. Til slutt i hvert program kommer en musikkvideo av sangen som ble introdusert tidligere i programmet. Hver sang i serien får altså en melodisk, klanglig og rytmisk gjennomgang før musikkvideoen blir vist til slutt. Intensjonen med dette er muligens å vise hvordan en sang er bygd opp, og hvilke musikalske byggesteiner som er benyttet i sangens komposisjon. Man viser altså grunnelementene i musikken først, før man ser på helheten, musikkvideoen, i slutten av hvert program.

\section{Teoretiske perspektiver}

Som teoretisk fundament for analysen av multimodalt samspill og meningsskaping har jeg valgt å anvende sosialsemiotikk. Michael Halliday, som er sosialsemiotikkens grunnlegger, sier i forordet til An Introduction to Functional Grammar (1994) følgende: «It is an introduction to functional grammar because the conceptual framework on which it is based is a functional one rather than a formal one». Dette er en teoriretning som er anvendelig for å undersøke hvordan mening skapes i tekster, og det er en bruksteori som gir analysekategorier for analyse av samspill mellom ulike modaliteter. Med uttrykket modalitet mener jeg selvstendige, meningsbærende systemer som muntlig og skriftlig verbalspråk, bilder, levende bilder og lyd (Maagerø \& Tønnessen, 2014, s. 24-41). Halliday var mest opptatt av språket i bruk, men senere har teoriene hans blitt overført til andre modaliteter som bilder, musikk og arkitektur (Kress \& van Leeuwen, 2006). Et teoretisk bidrag fra sosialsemiotikken er de tre metafunksjonene som i ulik grad er til stede og realisert i ethvert uttrykk. En verbalspråklig setning vil 
uttrykke ideasjonelt meningsinnhold, som betegner en meningsskaping om verdenen. Uttrykket vil samtidig skape en relasjon mellom uttrykket og den man kommuniserer med, og dette er den mellompersonlige meningsskapingen. Til slutt vil selve uttrykket inngå i en helhetlig sammenheng, og sørge for tekstuell meningsskaping (Halliday, 1978).

Det har vært diskutert om Hallidays lingvistiske teori lar seg overføre like lett til musikk som for eksempel til visuelle uttrykk (van Leeuwen, 1999, s. 190). van Leeuwen mener det kan være vanskelig å skille metafunksjonene fra hverandre når man undersøker musikk og lyd. Kan musikk ha et ideasjonelt meningspotensial? Han hevder følgende: «Sound does have its ideational resources, but they have to be realized on the back of interpersonal resources» (1999, s. 191). Musikk ikke er så spesialisert som språk og visuelle framstillinger, dermed vil det være vanskelig å få det til å passe inn i metafunksjonskategoriene. Musikken har en ideasjonell side, men han sier at den vil være vanskelig å beskrive uavhengig av den mellompersonlige- og tekstuelle metafunksjonen (van Leeuwen, 1999, s. 190). Han spør i stedet hva man kan anvende semiotiske ressurser som dynamikk og tonehøyde til i tale og musikk.

Musikkviteren Johnny Wingstedt har kategorisert Hallidays metafunksjoner ytterligere (Wingstedt, 2012, s. 187). Tekstuell meningsskaping blir delt opp i en temporal- og intermodal funksjon. I temporal funksjon etablerer musikken kontinuitet og definerer form, stuktur og avgrensning. Når musikken har en intermodal funksjon ser man på hvordan musikken forholder seg til filmbildene. Relasjoner mellom musikk og filmbilder kan være kongruente, komplementerende, kontrasterende eller konkurrerende. Når han snakker om ideasjonell meningsskaping, deler han den inn i en informativ-, deskriptiv- og emotiv (observert) funksjon. Under interpersonell mening (mellompersonlig meningsskaping), finner vi emotiv (opplevd) -, veiledende- og retorisk funksjon. Til forskjell fra den observerte emotive funksjonen under ideasjonell 
meningsskaping, fungerer altså den emotive funksjonen i mellompersonlig meningsskaping som opplevd. Når seere av en film berøres følelsesmessig av filmmusikken, er musikkens funksjon mellompersonlig og det er en av musikkens mest grunnleggende funksjoner (Wingstedt, 2012, s. 186). Det kan virke som Wingstedt løser problemet van Leeuwen har med metafunksjonene, ved å dele de ytterligere inn og la metafunksjonene gripe over i hverandre. I en senere artikkel viser Wingstedt (2018, s. 143) et analyseskjema der første kolonne har en notetranskripsjon. I neste kolonne viser han hvilke ressurser i musikken som er anvendt, og i den siste kolonnen hvilke meningspotensial som gjør seg gjeldende i de ulike metafunksjonene. Innenfor sosialsemiotikken har også Thibault (2000) og Bauldry \& Thibault (2006) utviklet analyseskjemaer hvor man viser hvordan Hallidays modell for språk også kan anvendes til blant annet film, der musikk utgjør en sentral meningsskapende ressurs.

I senerere tid har Per Ledin og David Machin (2018) reist en kritikk rettet mot det å anvende Hallidays metafunksjoner i bildeanalyser. De mener at Hallidays teorier fungerer godt til språkanalyser, men at det kreves tilpasninger for at de skal bli anvendbare på visuell kommunikasjon: «While these three metafunctions are important for understanding a social semiotic approach to language, they are, however, not so useful for analysing visual communication» (2018, s. 18). De hevder at det å analysere multimodale tekster gjennom et analyseapparat som var ment for verbalspråk, kan kreve supplerende faglige perspektiver slik at ikke kvaliteter og affordanser ved ulike semiotiske materialer går tapt dersom alt beskrives og analyseres gjennom Hallidays lingvistiske analyseapparat (2018, s. 25). De unngår også å bruke ordet modalitet, i stedet benyttes ord som musikk og filmbilder på ulike meningsbærende systemer. Jeg mener imidlertid at Hallidays teorier om verbalspråket i bruk også kan være overførbart til andre semiotiske systemer som for eksempel musikk, men da med tilpasninger knyttet til modalitetenes egenart. 
Når det gjelder hva musikk kan kommunisere, tok Deryck Cooke allerede i 1959 tak i denne problemstillingen. Han forsøkte å forklare hvordan musikk kan kommunisere et meningsinnhold, men da på verbalspråkets og visuelle framstillingers premisser (1959, s. 3). Dette spørsmålet er altså sentralt med tanke på den ideasjonelle metafunksjonen. Kan musikk kommunisere et meningsinnhold? Det er muligens her noe av problemet kan ligge når man anvender Hallidays metafunksjoner på andre meningssystemer enn verbalspråk, siden musikk har en helt annen affordans enn verbalspråket, og motsatt. Begrepet affordans er knyttet til de ulike mulighetene og begrensningene en modalitet har til å uttrykke mening, jf. Kress (2010, s. 79-80), og musikk gir særegne muligheter for meningsskaping. I en tidligere artikkel (Moskvil, 2015, s. 161) har jeg, i likhet med Nicholas Cooke (1998, s. 98-106) og van Leeuwen (2005, s. 256), argumentert for at ulike modaliteter av og til kan overlappe meningspotensialet hos hverandre, men at de aldri vil kunne uttrykke helt det samme. Noe av nøkkelen for å få Hallidays metafunksjoner til å fungere som analysekategorier utover det verbalspråklige, innebærer å ha et bevisst forhold til at modaliteter har ulike affordanser, altså muligheter og begrensninger.

I mitt analysemateriale er rytme en framtredende ressurs for meningsskapingen. Rytme er en semiotisk ressurs som blir anvendt i ulike modaliteter. Man kan for eksempel undersøke rytmen mellom bilder og tekst i ei bok, eller selve rytmen i musikk. van Leeuwen mener at rytme er forankret i menneskets biologi (2005, s. 181), og at «The essence of rhythm is alternation alternation between two states: an up and down, a tense and a lax, a loud and a soft, a night and a day, (...)» (2005, s. 182). På bakgrunn av denne biologiske forståelsen av rytme, vil mennesket også relatere meningspotensialet til tempoet i musikken kroppslig. Enkelt forklart vil musikk i et rolig tempo uttrykke mindre energi, enn musikk som går i et raskt tempo. Dette er fordi mennesket kan relatere tempoet i musikken til energien de bruker for å få ulike hjerteslag/puls (van Leeuwen, 1999, s. 39). Samtidig er det viktig å være 
bevisst på at musikk i et rolig tempo kan ha drivende rytmiske spenninger som også kan frembringe mye energi til musikken. Cooke (1959) har en lignende innfallsvinkel til rytmer. Han undersøker hva forskjellige rytmer er assosiert med på bakgrunn av ulike kroppslige bevegelser, og mye av teoriforankringen til van Leeuwen (1999) og Machin (2010) er inspirert av hans tanker og teorier. Cooke tar utgangspunkt i ulike verker fra klassisk musikk. I en gjennomgang av et stykke av Schubert i hurtig tempo i 6/8-takt sier han følgende om musikkens meningspotensial, forankret i det kroppslige: «There is surely no need to expatiate on the connection with walking and running feet, and the beat of the heart» (Cooke, 1959, s. 99). Til slutt er det også viktig å huske på at meningspotensialet som oppstår også vil være forbundet med kulturelt etablerte konvensjoner for organisering av temporale meningsstrukturer (Kvåle, 2012, s. 81).

\section{Transkripsjon og analysemåte}

I mine analyser av det musikalske som multimodalt uttrykk, har det vært hensiktsmessig å foreta transkripsjoner for å få en plattform å referere til. På denne måten får man fryst uttrykket, eller satt det på pause, slik at man kan studere det grundigere. Uansett hvordan man forsøker å transkribere, vil materialet kunne endre karakter og man sitter igjen med en fortolking av uttrykket, som om man oversetter ei bok til et nytt språk. Dessuten vil man jo også risikere å miste et mer helhetlig meningspotensial som materialet uttrykker i tid og rom gjennom avgrensede transkripsjoner.

Siden jeg har valgt å fremheve det rytmiske i Tusen plommer, har det vært viktig å velge en metodisk innfallsvinkel som harmonerer med dette aspektet ved materialet. Rytme er gjentagende, noe som går igjen og igjen, selv om intervallene og hastigheten er langsom (van Leeuwen, 2005, s. 182). Det rytmiske aspektet i videoen er framtredende, både i musikk og bilder, og både på et makro- og et mikronivå. Det rytmiske får derfor en funksjonell tyngde, 
jf. Løvland (2007, s. 26), både i musikken, filmbildene, sangteksten og det multimodale samvirket. Ulike multimodale tekster krever altså ulike analytiske tilnærminger basert på uttrykkets egenart, og derfor er rytmen i det multimodale materialet styrende for hvordan jeg analyserer videoen.

van Leeuwen viser i sin bok Introducing social semiotics (2005) ulike tilnærminger til multimodalt samspill. Han sier at rytme, ved siden av komposisjon, er den viktigste ressursen for sammenheng i multimodale tekster, de er selve «livsnervene» (2005, s. 181). Kohesjonsmekanismen til rytmen i en multimodal tekst er en veksling av modaliteter som er knyttet til tekstens tidsdimensjon (Maagerø \& Tønnessen, 2014, s. 42).

Spørsmålet blir da hvordan man skal operasjonalisere den multimodale analysen. Hvilke rytmiske samspill har de ulike modalitetene seg imellom? Jeg har valgt å transkribere musikken til noter for å få den ovennevnte plattformen å drøfte og analysere ut ifra. Etter å ha undersøkt det rytmiske aspektet i musikken, vil jeg se på det rytmiske samvirket mellom sangteksten og rytmen i musikken. Når jeg senere i analysen kobler klipperytmen til filmbildene sammen med musikkens rytme, vil jeg la musikkens rytme og puls ligge til grunn for transkripsjonen. Dermed lar jeg ikke sekunder og minutter styre transkripsjonen, slik for eksempel Baldry \& Thibault (2006), Machin (2010), Eriksson \& Machin (2018) og Ledin \& Machin (2018) gjør i sine transkripsjoner og analyser av videoer som inneholder musikk. I analysearbeidet vil jeg også benytte Hallidays metafunksjoner for å vise hvordan og på hvilken måte meningsskaping realiseres i videoen forstått som multimodal tekst.

Siden mye av innholdet i filmbildene går tapt når man fokuserer på klipperytmen, gir jeg her et kort resymé av handlingen i videoen: 
Sekvensen starter i en bygård hvor et brassband kommer løpende ut av en kjellerinngang. I bakgrunnen hører vi trommerytmer. Så begynner ei jente å synge første verset av sangen Tusen plommer. Filmbildene viser at hun sitter på en liten vogn som kjører på skinner i gangen ut av bygården. Rundt henne er det barn og gjøglere som danser rytmisk til musikken. Av og til dukker det opp korte klipp av ei dame som kan se ut til å være regissøren på filmsettet. Hun bærer på ei stor lampe. Filmbildene viser altså opptakten til en musikkvideoinnspilling. Musikken vi hører fremstår derimot som ferdig for innspilling. Når denne jenta synger første vers en gang til, befinner hun seg inne i en bygård som er pyntet med vimpler. Der er det også mange barn og gjøglere i fargerike kostymer. Mot slutten ser vi at aktørene fyller en kurv som jenta holder full av plommer, gjengitt i figur 2. Hele tiden er det rytmisk bevegelse og dans blant de ulike aktørene i filmen.

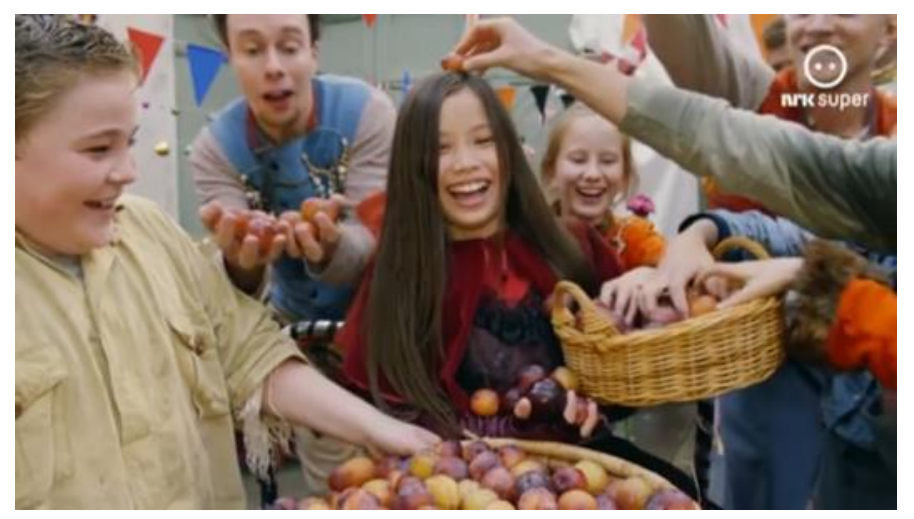

Figur 2: Filmbildene viser overflod av plommer mot slutten av sekvensen.

\section{Analyse}

Jeg velger, som sagt, å først transkribere musikken til noter. Transkripsjonen er forholdsvis enkel, og jeg har latt musikkens metriske struktur stå i fokus. Jeg har derfor ikke transkribert hele arrangementet av musikken som viser det totale lydbildet med alle instrumentene man kan høre. Jeg har heller valgt å sette søkelys på det framtredende i sangen. Hele transkripsjonen ligger som vedlegg til artikkelen. Når det gjelder analysen av sangteksten har jeg valgt å 
undersøke hvordan det rytmiske i sangteksten samspiller med pulsen til musikken. Jeg undersøker også hvordan meningsinnholdet til sangteksten og filmbildene forholder seg til hverandre.

Noe av det første jeg blir oppmerksom på når jeg hører musikken, er at det er noe som lugger litt i musikkens rytme. Opprinnelig ble melodien til sangen Tusen plommer komponert i 4/4-dels takt, men arrangør John Vinge har skrevet den om til 7/8-dels takt. Enkelt forklart teller man raskt til 7 istedenfor 8 i løpet av en takt, hver takt vil da «mangle» en åttendel i forhold til originalen, som vist i figur 3 . I taktene er åttendelene gruppert slik 3+2+2:

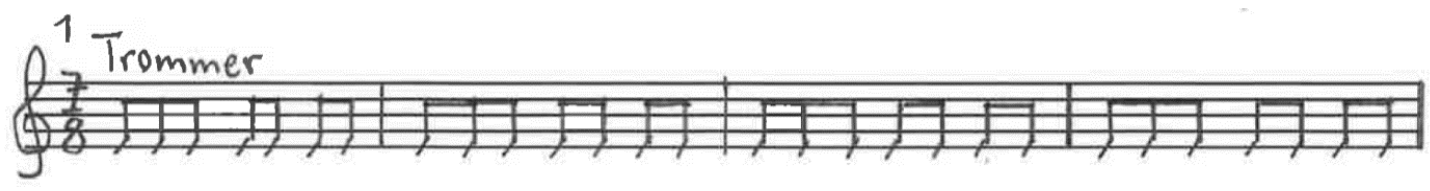

Figur 3: Oppbygningen av 7/8-dels takt.

Hvis man ikke har inngående kjennskap til skjeve takter, vil dette kanskje ikke være så framtredende. Muligens vil man oppleve det som om musikken snubler litt i hver takt. Musikk med slik taktinndeling finner man tradisjonelt på Balkanhalvøya, og i løpet av de siste tiårene har musikk herfra blitt mer tilgjengelig etter at landene åpnet opp på 1990-tallet. Det er komplisert å si noe om hvorfor musikken er bygd opp etter dette taktmønsteret, men det er gjennom dansestegene at denne skjeve taktarten faller på plass. I bulgarsk folkedans har for eksempel dansene Chetvorno Horo og Lesnoto samme rytmiske oppbygning, (3+2+2).

Når det gjelder den tekstuelle metafunksjonen, eller oppbygningen til sangen, starter den med at man hører 7/8-dels rytme fra trommer i 4 takter før brassorkesteret setter inn i 4 takter, se figur 4 . 

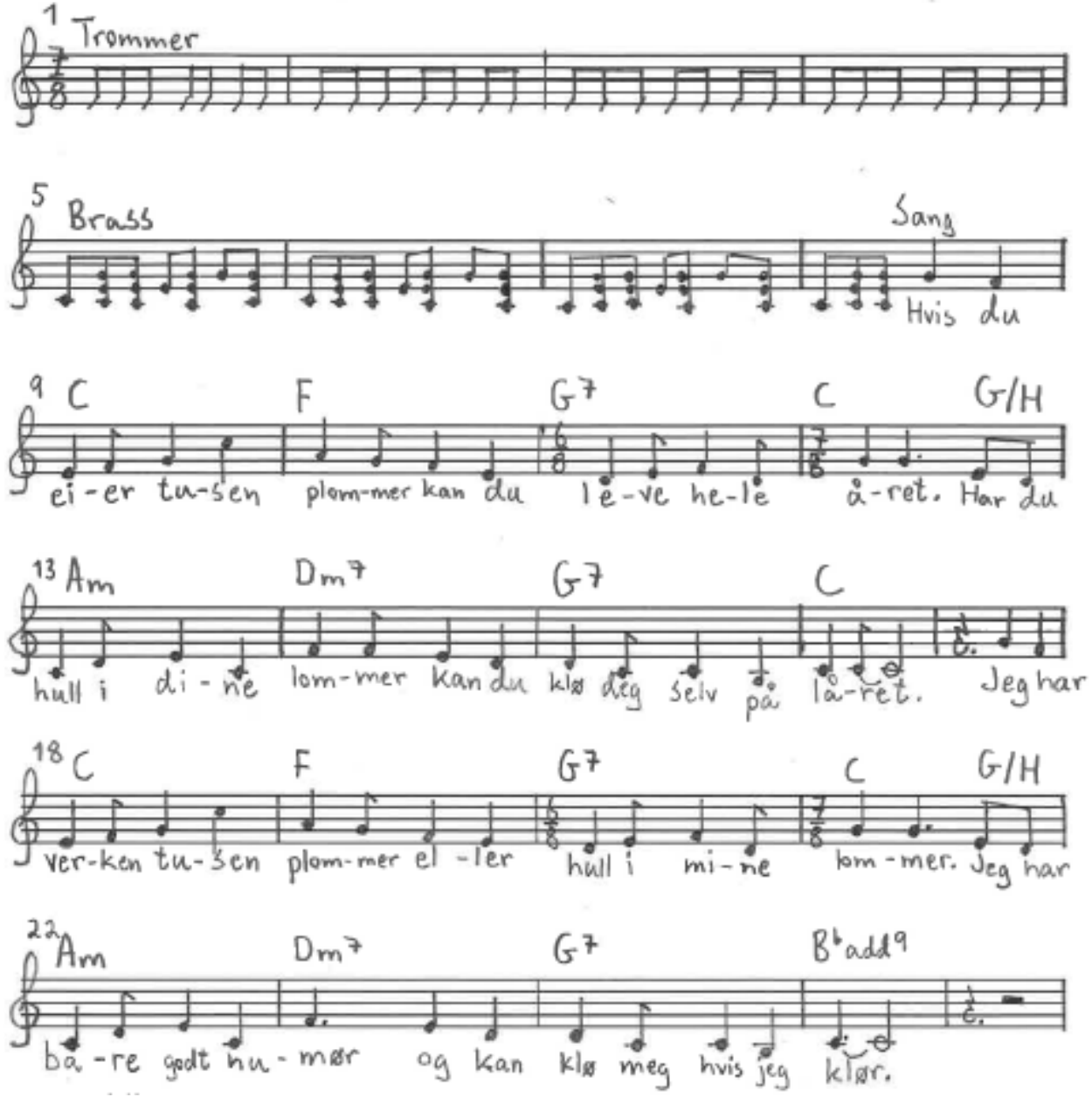

Figur 4: De 26 første taktene.

At man făr høre denne rytmen spilt med trommer i 8 takter før sangteksten setter inn, gjør det muligens enklere å bli kjent med en ny, rytmisk versjon av sangen. Man må også huske på at man tidligere i programmet har blitt introdusert for melodiens oppbygning, slik at det da vil være enklere å høre sangen i 7/8-dels takt, jf. den tekstuelle metafunksjonen. I takt 5-8 blir vi introdusert for brassbandet. De ulike brassinstrumentene spiller på ulike åttendeler, og har ulike betoninger, som også bidrar til å forsterke den rytmiske oppbygningen. Den rytmiske framdriften blir både stødig og haltende på en gang, nesten som å kjøre en rytmisk berg- og dalbane. Rytmene skaper mye energi og spenning, den kommuniserer altså et meningspotensial som mottakere kan relatere seg kroppslig til, jf. den 
ideasjonelle metafunksjonen. Opplevelsen av tempoet er hurtig, mye på grunn av at alle åttendelene blir spilt av orkesteret.

Pulsen til rytmen vil hovedsakelig ligge på den første åttendelen i hver takt, men også litt på den fjerde og sjette, jf. 3+2+2-strukturen. van Leeuwen sier at «the pulse (...) fall on the main notes, the notes that are most indispensable for getting the musical message across» (1999, s. 40). Det er altså på den første åttendelen i hver takt, downbeat, at viktig informasjon 3 vil ligge. I mitt eksempel vil det være interessant å se på sangteksten og klipperytmen til filmbildene som ligger på dette betonede taktslaget som blir «salient» og får betydning for den multimodale meningsskapingen. Det at noe er salient vil ifølge Kress si at enkelte elementer i den multimodale teksten er gjort framtredende for å fange oppmerksomheten til seerne (Kress, 2003, s. 4).

Et interessant brudd i sangen er at man har fjernet ytterligere en åttendel i takt 11 og 20, se figur 4, og som man ser av transkripsjonen går musikken her i 6/8-dels takt. Disse bruddene tilfører ekstra energi i helheten, det blir som om en framtredende oppmerksomhetsfanger sier følg med. Igjen ser man at rytmen til musikken bidrar til å fange lytterens oppmerksomhet, og slik realiseres også den mellompersonlige metafunksjonen. Machin sier: «rythms can also be jerky, as in a walking with a limp or struggling to walk» (2010, s. 129), og han referer til Deryck Cooke som hevder at dette kan vil kunne skape spenning og energi (1959, s. 100). Jeg opplever den raske musikken i 7/8-dels takt som litt haltende, den mangler en åttendel, samt at den skifter mellom ulike rytmiske inndelinger. Brassorkesteret bidrar også til å spille hver eneste åttendel gjennom hele sangen. Transkripsjonen avdekker i dette eksempelet at den rytmiske oppbygningen muligens ikke er så åpenbar ved kun én gjennomlytting: Man får innsikt i hvordan musikken er oppbygd for å skape energiske spenninger, som igjen tilfører et meningspotensial som har med rytmisk

3 Informasjon handler her om det musikalske meningsinnhold, «..the musical message» (van Leeuwen, 1999, s. 40). 
energi å gjøre. Dette er en egenskap ved rytme som semiotisk ressurs i musikken. Sangen inneholder også en modulasjon fra C-dur til D-dur mellom første og andre vers. Dette kan også regnes som en semiotisk ressurs i musikken som kan legge grunnlaget for et løft i energinivået til sangen.

\section{Multimodalt samspill}

Før jeg viser hvordan samspillet mellom musikk og filmbilder arter seg, undersøker jeg samspillet mellom rytmen i musikken og sangteksten. van Leeuwen hevder at «the pulses mark the sounds and movements which carry the greatest information value in the given context» (2005, s. 189). I den følgende sangteksten har jeg derfor valgt å utheve med fet skrift det ordet som kommer på første betonte åttendel i hver takt, altså pulsslaget. Da ser teksten slik ut:

Hvis du eier tusen plommer kan du leve hele året.

Har du hull i dine lommer kan du klø deg selv på låret.

Jeg har verken tusen plommer eller hull i mine lommer.

Jeg har bare godt humør og kan klø meg hvis jeg klør.

Som man ser av uthevingen av teksten på første pulsslaget i hver takt, er det her nøkkelordene i sangteksten ligger. Disse ordene vil alene gi et forenklet sammendrag av innholdet i sangteksten. Ut ifra et rytmisk perspektiv viser denne sammenstillingen at sangtekstens innhold blir forsterket av dette sterke slaget i musikken og rytmen bidrar til at sangteksten trer tydeligere fram. De samme ordene som det første slaget i hver takt lander på i teksten, er identisk med originalversjonen som går i 4/4-dels takt.

Etter å ha undersøkt det rytmiske fundamentet i musikken og sangteksten, er det interessant å undersøke hvordan også filmbildene samspiller med de 
andre modalitetene. Jeg har derfor tatt tak i hvordan klipperytmen til filmbildene forholder seg til dette. Teknisk sett består sekvensen av 60 filmklipp4 som er fordelt på 1 minutt og 35 sekunder. Det gir i snitt 1,6 sekunder pr. filmklipp, eller et filmklipp per takt. Når jeg skal undersøke det rytmiske samspillet mellom musikk, sangtekst og filmbilder, har jeg limt inn første bilde i hvert filmklipp i notetranskripsjonen. Denne framgangsmåten er inspirert av Nicholas Cook (1998, s. 160-167) som også lar musikkens takter styre transkripsjoner av musikkvideoer. Jeg velger å ta utgangspunkt i de 17 første taktene. Transkripsjonen vil da se slik ut, gjengitt i figur 5:
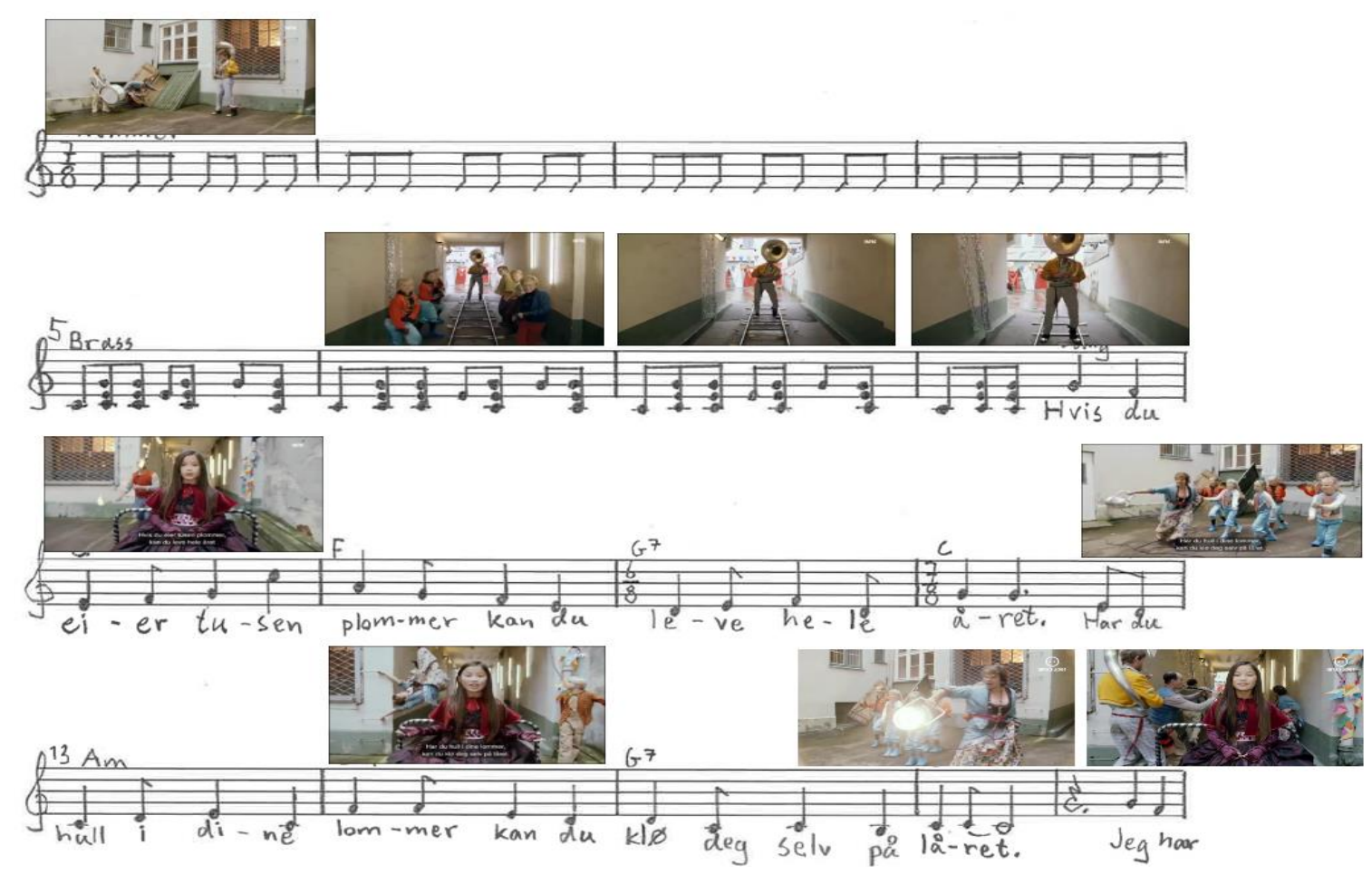

Figur 5: De 17 første taktene i musikken satt sammen med filmklipp.

4 Et begrep som vi møter i transkripsjon av film er shot, som betyr kamerainnstilling. Et shot kan defineres som et sammenhengende, uavbrutt opptak, der kameraet enten er i bevegelse eller holdes i ro (Engelstad \& Tønnessen, 2011, s. 77). I analysen bruker jeg uttrykket filmklipp, som anvendes synonymt med shot i en norsk kontekst. 
I introen til videoen, takt 1-9, legges nye filmklipp på det første slaget i hver takt. Viktig informasjon vil ifølge van Leeuwen ligge på dette betonte slaget i musikken (2005, s. 183). Denne taktfaste klipperytmen er med på å etablere den mellompersonlige metafunksjonen: Filmbilder og musikk spiller taktfast sammen slik at det er lett å la seg rive med av videoen. I tillegg zoomes det av og til inn på aktørblikkene. Disse grepene bidrar ytterligere til å etablere en relasjon mellom videoen og seerne. I begynnelsen av de første filmklippene ser vi en musiker som spiller et blåseinstrument. I filmbildene ser vi også barn som danser med hendene, og gjøglere som sjonglerer med fakler. De raske bevegelsene i filmbildene samspiller nesten identisk med åttendelene som brassorkesteret spiller. Dette er vanskelig å se på transkripsjonen, fordi de levende filmbildene presenterer mye mer informasjon enn det de innlimte, «frosne» bildene i transkripsjonen viser.

Fra takt 35 sammenfaller klippingen av filmbilder med det første slaget i takten til musikken og ordet tusen i sangteksten. De ulike modalitetene trekker her i samme retning, og vi får et fortettet uttrykk. Det rytmiske samvirket mellom de ulike modalitetene faller på samme betonte slag i takten, noe som er med på å framheve meningspotensialet. Filmbildene zoomer også inn for hvert klipp som vises. Vi ser at blikket til jenta kommer nærmere og nærmere for hvert nye filmklipp. Samtidig synger ikke jenta, hun hvisker ordene tusen plommer. Seere kan høre at den hviskende jentestemmen er mikset foran brassorkesteret, noe som bidrar til en opplevelse av å være nærmere jenta. På denne måten blir jentas stemme forsterket i forhold til resten av musikken, nærmest en auditiv zooming som gjør stemmen salient, jf. van Leeuwen (1999, s. 16). Dette er med på å etablere en nærhet til seerne av videoen, og den mellompersonlige metafunksjonen blir realisert gjennom disse grepene. Et slikt funn kan igjen være vanskelig å oppdage og dokumentere, fordi alt skjer så fort. Men det er lettere å avdekke i en transkripsjon når man som her i figur 6 analyserer de ulike modalitetene i samspill. 


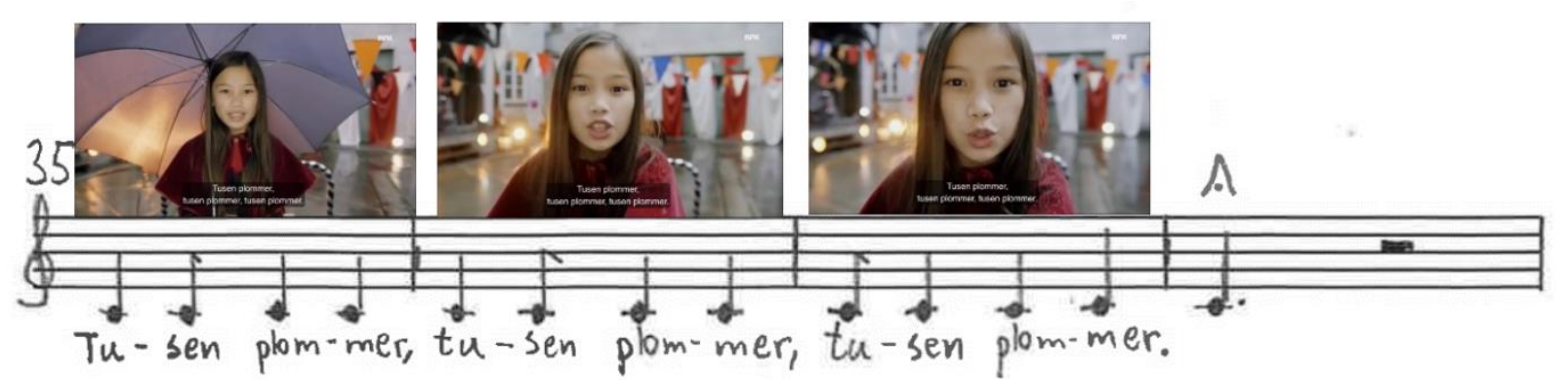

Figur 6: Filmbildene, sangteksten og første pulsslaget til musikken følger hverandre.

Fra takt 39-42 veksler filmbildene mellom å vise et nærbilde av sangeren og dansende barn. Sangeren retter blikket direkte mot seere av videoen, mens hun sier «en, to, tre, en, to, en, to», om og om igjen. Denne tellingen finner man ikke i den originale sangteksten. Den er tillagt videoproduksjonen, og fungerer som en teoretisk underbygning for hvordan man kan underdele en 7/8-dels takt. Det direkte blikket fra sangeren sier noe om at det er noe viktig, nærmest en hemmelighet, som blir fortalt, og dette visuelle virkemiddelet er med på å realisere den mellompersonlige metafunksjonen. I og med at filmbildene med jenta er filmet som nærbilder, legger det grunnlaget for en sosial nærhet mellom aktøren og seere. Zhao og Zappavigna (2017, s. 1740) skriver at blikkets funksjon i selfier kan fungere slik, og jeg vil påstå at det vil ha samme effekt i filmbildene fra analysematerialet. I bakgrunnen ser vi også at den lilla paraplyen snurrer rundt bak jenta mens denne sekvensen pågår, og det er som om paraplyen visuelt underbygger tellingen av en 7/8-dels takt.

Jeg har nå vist de mest sentrale stedene i musikkvideoen hvor klippingen av filmbildene sammenfaller med første pulsslaget i takten til musikken. Klippingen er altså med på å skape mening, og må forstås som en semiotisk ressurs i filmmediet. Som analytiker reagerer jeg likevel ikke i stor grad når filmbildene ikke blir klippet på dette betonede taktslaget til musikken. Det viser muligens at rytmen til musikken er mer framtredende og har en ledende rolle i forhold til den litt vilkårlige klipperytmen til filmbildene. Et nokså identisk samspill mellom første pulsslaget i takten til musikken, klippingen 
av filmbilder og sangtekst finner vi også i takt 69-72, altså mot slutten av musikkvideoen.

\section{Hvilke multimodale meningspotensial kommuniserer musikkvideoen?}

Analysen av musikkvideoen viser at Sangfoni tar sikte på å revitalisere kjente barnesanger (Aarvig, 2017), samtidig som de viser hvordan musikken er bygd opp. Gjennom analysen har jeg forsøkt å vise hvordan det multimodale samspillet mellom musikk, sangtekst, filmbilder og klipperytme arter seg i Tusen plommer. Men hva er det som egentlig har blitt kommunisert?

Hvis man i første omgang undersøker sangteksten, viser den at du kan være lykkelig uten å eie mange plommer, og at man kan klø seg på låret uten å ha hull i lommene. Man skal ikke tolke denne teksten for bokstavelig, det er en type nonsensdikt som i seg selv krever en inngående analyse, noe jeg har valgt å ikke gjøre her. Men for mange vil ordet plommer konnotere noe positivt. Noen verbalutsagn i sangen kan forstås som holdningsladet, og kanskje som et opprør, om vi sammenligner denne teksten med eldre mer normative, oppdragende tekster. Et eksempel her er det frigjørende i tekstens oppfordring: «kan du klø deg selv på låret», i hvert fall for barn som har lært at en ikke skal klø på insektsstikk. Verbalteksten gir ingen svar på hvordan man kan bli lykkelig, men den viser at man kan ha godt humør uten å eie mange ting.

Samtidig viser filmbildene at jenta som synger får en kurv full av plommer mot slutten av videoen. Hun ser lykkelig ut. Her kan det diskuteres om det er et motstridende meningsinnhold mellom sangtekst og filmbilder. Filmbildene viser heller ingen som har hull i sine lommer, eller noen som trenger å klø seg på låret. Slik jeg opplever de to modalitetene her, er det filmbildene som er den ledende modaliteten i forhold til sangteksten. Det kan virke som om meningsskapingen man finner i sangteksten bare delvis ligger til grunn for det filmbildene viser. Samtidig er det kanskje regissøren sin tolkning av 
sangteksten at den utstråler mening rundt emner som lykke og godt humør. I så måte trekker de to modalitetene i samme retning.

Gjennom den rytmiske innfallsvinkelen til analysen av materialet har jeg vist at rytmen i de ulike modalitetene legger grunnlaget for mye av meningsskapingen. Selv om det ikke er noe automatikk i det, kan musikk i 7/8-takt skape spenning og energi. I musikkens rytme er det ofte de ørsmå forskyvingene og betoningene som ikke lar seg så lett transkribere, men som skaper energien. Man hører det når musikken begynner å svinge og generere energi, men det er vanskelig å forklare nøyaktig hva som skjer når dette inntreffer. Her ser man en svakhet med å transkribere musikk til noter, siden man mister de ørsmå detaljene når man bruker standardiserte, metriske notasjonssystemer. Vi har også sett at de energiske filmbildene, samt den hurtige, rytmiske filmklippingen i flere utdrag fra analysematerialet samspiller godt med meningspotensialet til den rytmiske musikken.

Når det gjelder informasjon som blir lagt på første slaget i takten til musikken, vil dette legge grunnlaget for hva det er mest sannsynlig at en mottaker av videoen vil sitte igjen med. Den rytmiske analysen av sangteksten viser at den er et solid dikterisk håndverk. De viktigste ordene i sangteksten ligger på det betonede taktslaget til musikken. Jeg har også vist at av og til sammenfaller klipperytmen til filmbildene og sangteksten med det første pulsslaget i takten til musikken. Dette er spesielt merkbart fra takt 35 og 69 hvor jenta hvisker «Tusen plommer, tusen plommer, tusen plommer». Et slikt funn ville vært vanskelig å oppdage og transkribere hvis jeg hadde latt sekunder og minutter styre transkripsjonen. Her ser man hvor viktig det er å la musikkens rytme og puls legge grunnlaget for transkripsjonen av det multimodale uttrykket.

Fra takt 39-42 teller jenta, som vi husker, åttendelsunderdelingene i 7/8-dels takt. Hun sier: «en, to, tre, en, to, en, to» fire ganger etter hverandre. Notasjonen til denne oppbygningen er vist i figur 3 tidligere i artikkelen. 
Det kan virke som om musikkvideoen Tusen plommer også er en opplæringsvideo i hvordan telle og forstå en 7/8-dels takt. Dette viser de 8 første taktene i sangen hvor trommer og brassband spiller inndelingen i denne taktarten. I sekvensene hvor jenta også hvisker ordet «Tusen plommer», virker dette som et rytmisk uttrykk som hjelper til med å forstå rytmen. Denne sekvensen er gjentatt to ganger i videoen, og det er også denne passasjen videoen avslutter med. Det er derfor nærliggende å tenke at noe av det største, musikalske meningspotensialet som modalitetene skaper sammen, er at musikkvideoen kan bidra til innlæring og forståelse av, hvordan musikk i 7/8dels takt er satt sammen, noe som kan legge grunnlaget for økt musikk- og kulturforståelse. Det å bruke ord eller telling for å lære nye rytmemønstre og sanger er noe man blant annet har benyttet seg av i opplæringen av klassisk indisk musikk eller trommetradisjoner i Kenya. Jeg vil påstå at det er enklere å spille rytmen på instrumenter når man først kan synge eller si den med stemmen. Også i Norge benyttes dette i innlæring av uregelmessige taktarter. Man kan for eksempel si «O-le-Ed-vard-An-ton-sen» for å lære rytmen til en 7/8-dels takt (Bergby, 2007, s. 108). Man får da bokstavelig talt smakt på rytmen gjennom en kroppslig tilnærming til musikken.

Vi har også sett at musikk i 7/8-dels takt kan legge grunnlaget for et energisk meningspotensial som i stor grad vil appellere til barn. Man vil kjenne rytmen av å høre musikken, men den enkle og lekne sangteksten gjør det også mer tilgjengelig for barn å kunne synge og være aktiv deltaker i det multimodale uttrykket, noe programserien også legger opp til. Jeg vil påstå at musikkvideoen inviterer til sang og deltakelse blant barn som ser den, og gjennom imitasjon av sangeren kan seere lære seg avansert rytmikk på en lekende og deltagende måte. I og med at programserien Sangfoni jevnlig blir sendt på NRK, i tillegg til at den også ligger på nettsiden til NRK, har serien et stort nedslagsfelt. I innledningen nevnte jeg at det fortsatt ikke har kommet nye læreverk i bokform til musikkfaget etter den nye læreplanen. Det kan tyde på at det allerede har skjedd en dreining bort fra læreboka i fysisk format, jf. 
Hanken \& Johansen (2013, s. 249) og Kempe \& West (2010, s. 177-182). I skrivende stund har blant annet forlagene Gyldendal (2020) og Cappelen Damm (2020) utviklet digitale læringsressurser i musikkfaget som er tilgjengelige for bruk i grunnskolen. Musikk og filmbilder vil muligens lettere og på en bedre måte, legge grunnlaget for oppnåelse av ulike kompetansemål i musikkfaget, enn det en tradisjonell lærebok vil gjøre. Jeg har ikke undersøkt om serien Sangfoni er tenkt brukt som en fast pedagogisk ressurs i skolen, men gjennom analysen ser vi blant annet at elevene vil kunne sitte igjen med kunnskap som har med hvordan en skjev 7/8-dels takt er oppbygd. Når man forstår hva som skjer i dette rytmiske fenomenet, vil man også lettere forstå andre avanserte rytmiske strukturer. Jeg mener at eksempelanalysen av en digital ressurs som Sangfoni, har vist at dette kan være et godt supplement til musikkundervisningen, og kanskje er det slike digitale ressurser som vil være den nye læreboka i musikkfaget. 


\section{Litteratur:}

Aarvig, E. (2017). Magisk musikkrealisme i Sangfoni. Hentet 27.01, 2019, fra https://rushprint.no/2017/05/magisk-musikkrealisme-i-sangfoni/

Aisato, L. (2009). Den store sangboken: Gyldendal Norsk Forlag.

Baldry, A., \& Thibault, P. J. (2006). Multimodal transcription and text analysis. London: Equinox.

Bergby, A. K. (2007). Rytme. I H. S. Blix \& A. K. Bergby (Red.), Øre for musikk (s. 94-111): Unipub.

Cappelen, D. (2020). Musikk. Hentet 31.10, 2020, fra https://skolenmin.cdu.no/_/2-trinn/musikk-5d6678f4af8e57001e904eo15ebd3b5aa7b890002d5709f8?showIntro=trues

Cook, N. (1998). Analysing musical multimedia. Oxford: Clarendon Press.

Cooke, D. (1959). The Language Of Music. New York: Oxford University Press.

Engelstad, A., \& Tønnessen, E. S. (2011). Film. [Oslo]: Cappelen Damm akademisk.

Eriksson, G., \& Machin, D. (2018). The Role of Music in Rediculing the Working Classes in Reality Television. I L. C. S. Way \& S. McKerrell (Red.), Music as Multimodal Discourse (s. 21-46). London: Bloomsbury Academic.

Gyldendal. (2020). Salaby Skole Musikk 1-2. Hentet 31.10, 2020, fra https://skole.salaby.no/1-2/musikk

Hake, K. (2006). Historien om Barne-TV: barndomsbilder 1960-2005. Oslo: Universitetsforlaget.

Halliday, M. A. K. (1978). Language as social semiotic. London: Edward Arnold. 
Halliday, M. A. K. (1994). An introduction to functional grammar. London: Arnold.

Hanken, I. M., \& Johansen, G. (2013). Musikkundervisningens didaktikk: Cappelen Damm Akademisk.

Kempe, A.-L., \& West, T. (2010). Design för lärande i musik: Norstedts.

Kress, G. (2003). Literacy in the new media age. London: Routledge.

Kress, G. (2010). Multimodality. London: Routledge.

Kress, G., \& van Leeuwen, T. (2006). Reading images: the grammar of visual design. London: Routledge.

Kvåle, G. (2012). Multimodalt samspill i bildeskriftkomplekser. En sosialsemiotisk undersøkelse av relasjoner mellom skrift og bilde. Universitetet i Agder.

Ledin, P., Höög, C. N., Tønnesson, J., \& Westberg, G. (2019). Den multimodala sakprosan. Sakprosa(4).

Ledin, P., \& Machin, D. (2018). Doing Visual Analysis - From Theory To Practice. London: SAGE Publications Ltd.

Ljones Øierud, G. (2011). Slik lyder Herrens Ord multimodalt - om multimodal meningsskaping. I T. R. Hitchin, A. B. Nielsen \& A. Veum (Red.), Diskursanalyse i praksis: metode og analyse (s. 49-78). Kristiansand: Høyskoleforlaget.

Løvland, A. (2007). På mange måtar (B. nr. 168). Bergen: Fagbokforlaget.

Maagerø, E., \& Tønnessen, E. S. (2014). Multimodal tekstkompetanse.

Kristiansand: Portal.

Machin, D. (2010). Analysing popular music. London: SAGE.

Moskvil, J. Ø. (2015). Musikkens meningsskaping i filmen Latcho Drom. I B. Markussen (Red.), Lydspor: når musikk møter tekst og bilder (s. 142-161). 
Kristiansand: Portal forlag.

Soldal, H. (2018). https://tv.nrk.no/serie/sangfoni. Hentet 27.01, 2019

Thibault, P. J. (2000). The Multimodal Transcription of Television Advertisement: Theory and Practise. I A. Baldry (Red.), Multimodality and Multimediality in the Distance Learing Age (s. 311-385). Camobasso: Palladino Editore.

Utdanningsdirektoratet. (2020). Læreplan i musikk. (MDDo5-02). Hentet fra https://www.udir.no/lk20/mddo5-02

van Leeuwen, T. (1999). Speech, music, sound. Basingstoke: Macmillan.

van Leeuwen, T. (2005). Introducing social semiotics. London: Routledge.

Wingstedt, J. (2012). Metafunktioner, dieges och interaktivitet. I G. Ternhag \& J. r. Wingstedt (Red.), På tal om musikproduktion (s. 182-196). Göteborg: Bo Ejeby Förlag.

Wingstedt, J. (2018). "If You Have Nothing To Say - Sing It!": On the Interplay of Music, Voice and Lyrics in the Advertising Jingle. I L. C. S. Way \& S. McKerrell (Red.), Music as Multimodal Discourse (s. 135-158). London: Bloomsbuty Academic.

Zhao, S., \& Zappavigna, M. (2017). Beyond the self: Intersubjectivity and the social semiotic interpretation of the selfie. New media \& society, 2O(5), 1735-1754. 


\section{Vedlegg:}

$$
\text { - Tusen plommer- }
$$

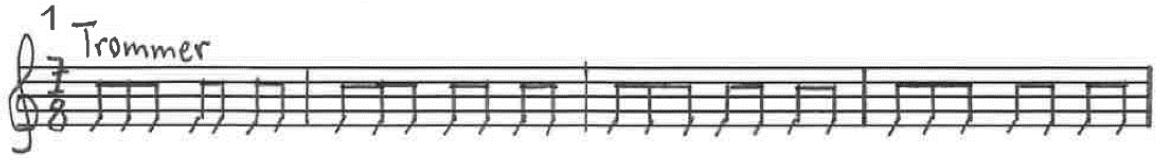
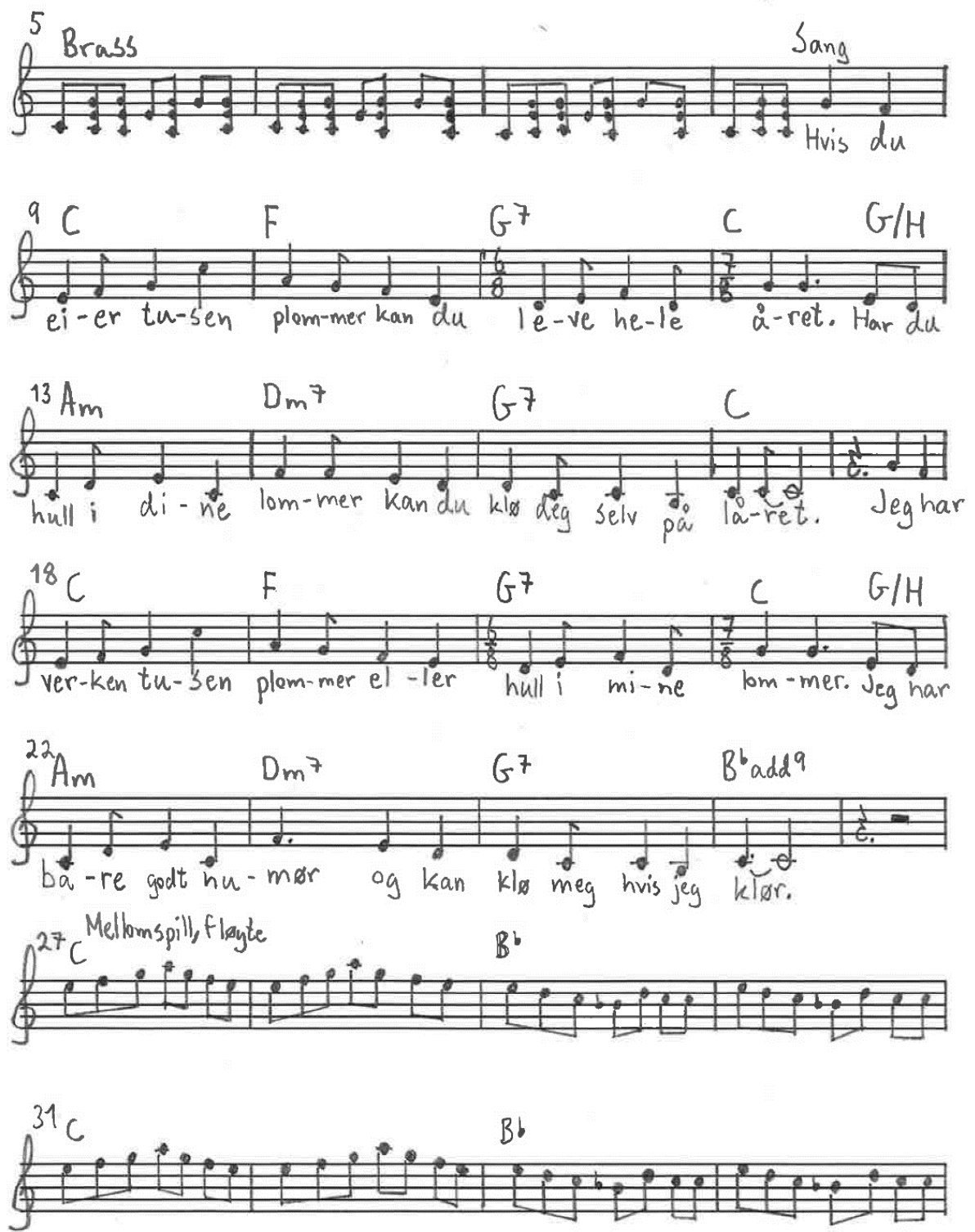


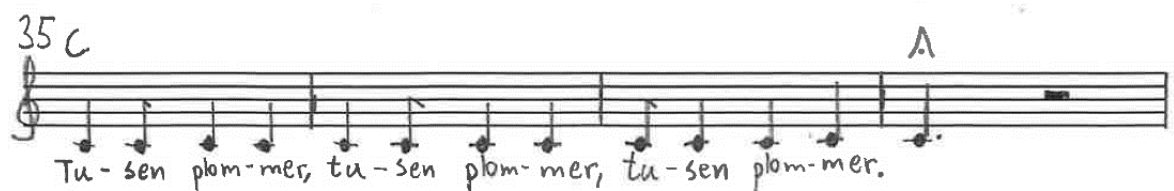

39 Sang +trommer

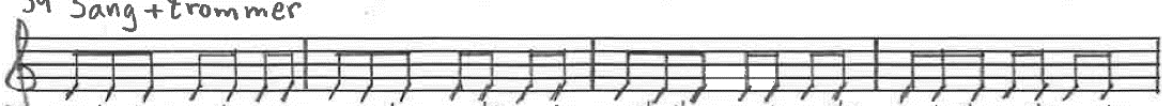

ento tre en toento ento tre ento en to en to tre ento ento énto treento en to
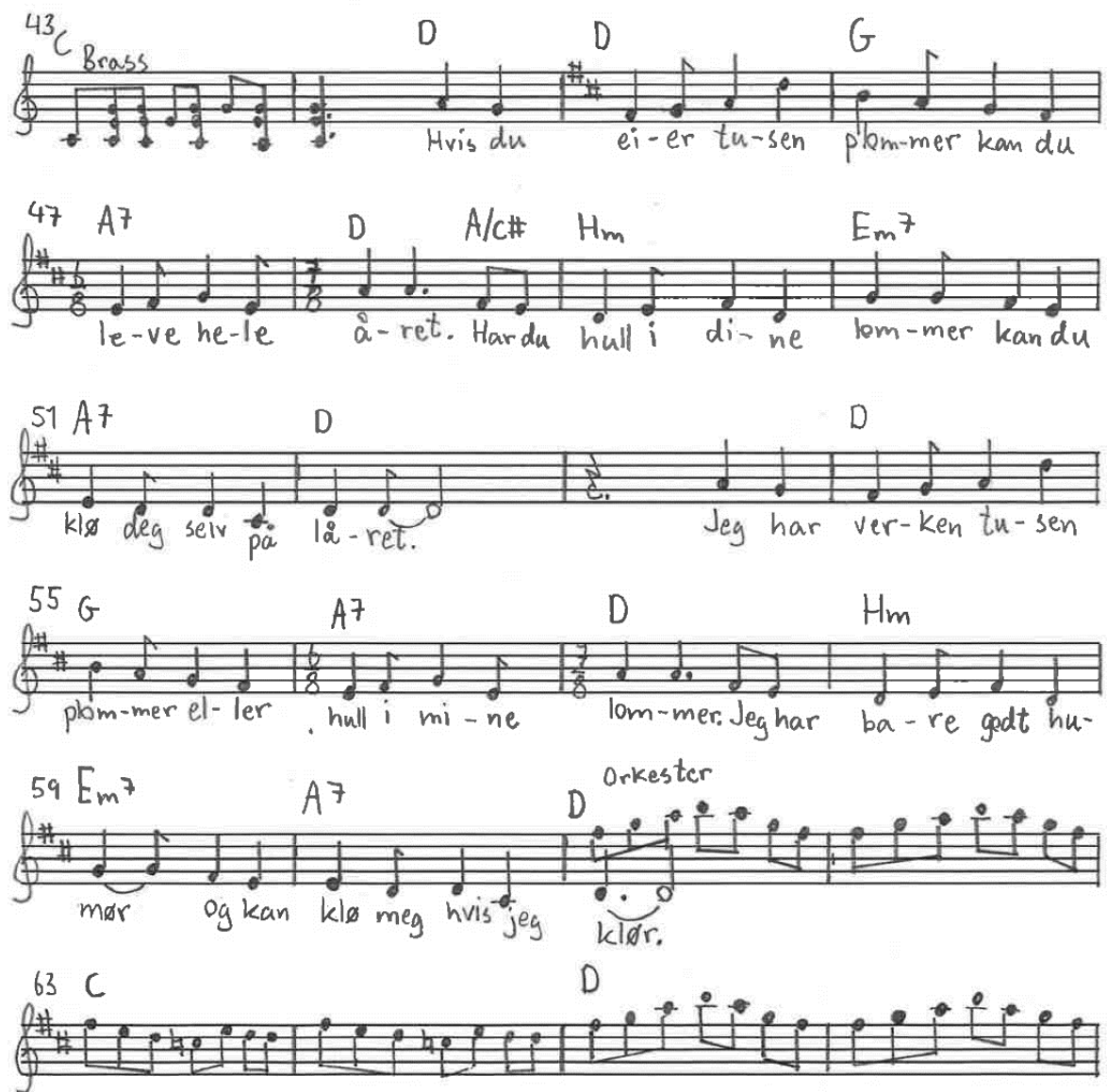

$-2-$ 

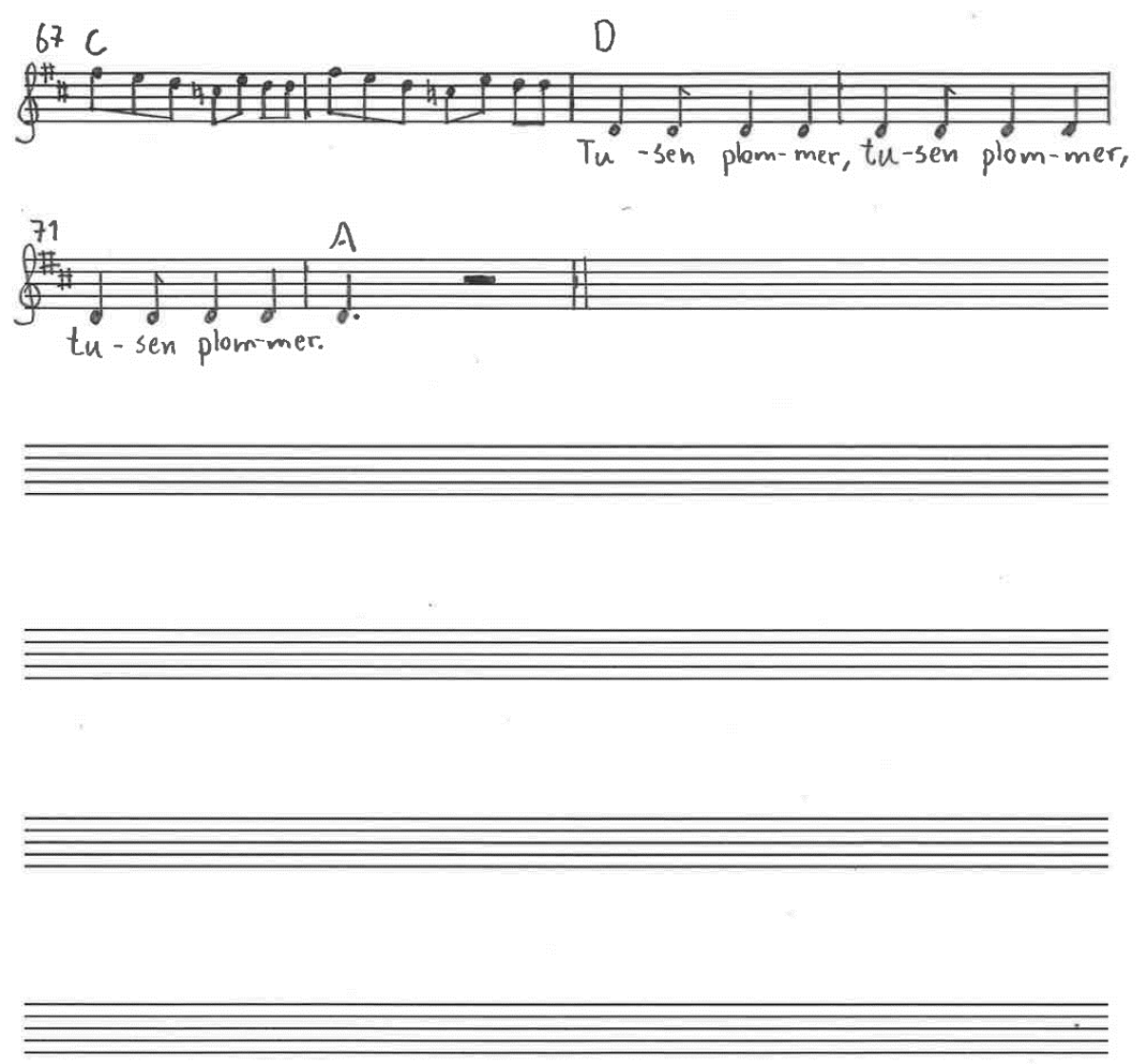

$-3-$

J. Ø. Moskvil 